\title{
КОНЦЕПЦІЯ ПСИХОЛОГІЧНОГО СУПРОВОДУ ОСВІТНІХ РЕФОРМ У ДІЯЛЬНОСТІ ПСИХОЛОГІЧНОЇ СЛУЖБИ
}

https://doi.org/10.37472/2707-305X-2020-2-1-9-1

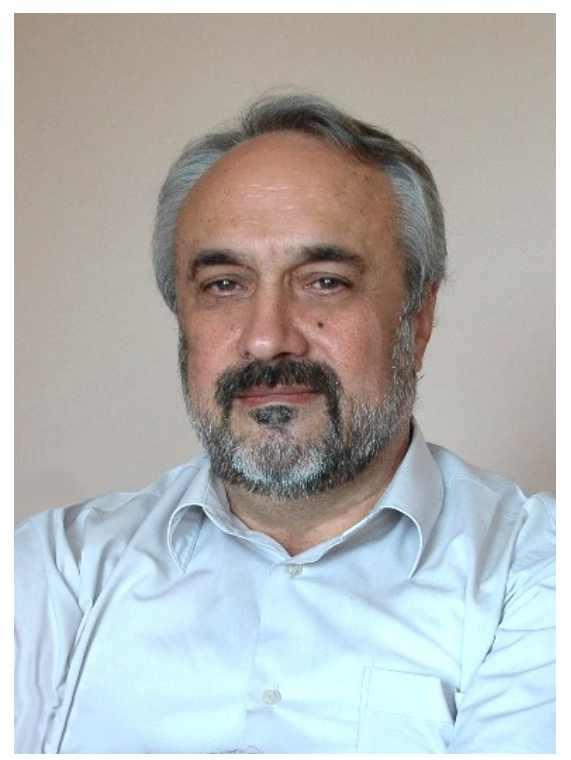

ПАНОК Віталій Григорович доктор психологічних наук, профресор, член-кореспондент НАПН України, директор Українського науковометодичного центру практичної психології $і$ сочіальної роботи, Національна академія педагогічних наук України, м. Київ, Україна

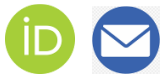

Анотація. у статті розглядаються питання удосконалення психологічної служби системи освіти. На основі аналізу роботи психологічної служби у закладах освіти виокремлено головні проблеми $i$ виклики, що постали нині у зв'язку з реформуванням системи освіти. Автор пропонує своє бачення шляхів розвитку і вдосконалення психологічної служби на основі розуміння ії як єдиної системи, що забезпечує психологічний супровід освітнього прочесу.

Ключові слова: реформа освіти; психологічний супровід; психологічна служба; практичні психологи; соціальні педагоги; теорія розвитку особистості; мета діяльності; принципи; структура; ліцензування.

Вступ. У системі національної освіти відповідно до статті 76 Закону України «Про освіту» (2017) діє психологічна служба, що забезпечує своєчасне і систематичне вивчення психофізичного розвитку здобувачів освіти, мотивів їхньої поведінки і діяльності з урахуванням вікових, інтелектуальних, фізичних, гендерних та інших індивідуальних особливостей; сприяє створенню умов для виконання освітніх і виховних завдань, соціального та інтелектуального розвитку здобувачів освіти, охорони психічного здоров'я, надання психологічної та соціально-педагогічної підтримки всім учасникам освітнього процесу відповідно до цілей і завдань системи освіти. У психологічній службі системи освіти задіяні практичні психологи, соціальні педагоги, методисти та директори (завідувачі) навчально-методичних кабінетів/центрів/лабораторій (МОН України, 2018; МОН України, 2019).

Сучасні тенденції розвитку освіти формують загальне спрямування діяльності психологічної служби, визначають стратегію ї̈ розвитку на найближчі роки (Кремень, 2008).

Концепція Нової української школи передбачає перезавантаження національної освіти з оновленням існуючого алгоритму професійної діяльності та переглядом методології роботи з учнями, батьками та вчителями, а також зміну акцентів і пріоритетів $з$ процесу на результат із використанням ефективних методів практичної психології та соціальної роботи (МОН України, 2016; МОН України, 2019).

Децентралізація в управлінні освітою, розширення прав і можливостей місцевих громад щодо впливу на освітній процес спонукають фахівців психологічної служби суттєво переглянути зміст і напрями психологічного і соціально-педагогічного супроводу всіх учасників освітнього процесу.

Складні соціально-економічні умови, у яких перебуває українське суспільство - російська агресія, економічна криза, пандемія COVID-19, політична нестабільність тощо - потребують від праців- 
ників психологічної служби надання допомоги постраждалим, учням, учителям і представникам громадськості для подолання різних психічних травм, постстресових розладів, труднощів соціальної адаптації, профілактики девіантної поведінки та інших проблем особистісного і мікросоціального характеру.

Дієвість освітніх реформ значною мірою залежить від ефективності їх психологічного забезпечення, адже саме психологічна служба спроможна визначати рівні й особливості індивідуального розвитку здобувачів освіти та застосовувати інструменти корекції його змісту і напрямів у освітньому процесі. Такі аргументи є підставою для розроблення нової концепції психологічного супроводу освітніх реформ у діяльності психологічної служби на найближчі роки (20212025).

Отже, метою цієї роботи є визначення шляхів і методів оновлення психологічної служби системи освіти як у методичному, так і в організаційному аспектах для підвищення ефективності їі функціонування і приведення у відповідність до нових вимог суспільства і реформи освіти.

Завдання

1. На основі теоретичного аналізу сучасного стану і вивчення досвіду функціонування психологічної служби у системі освіти визначити основні проблеми в її діяльності та виклики, які постають перед нею у контексті соціальної ситуації у суспільстві загалом і реформування освітньої галузі зокрема.

2. Запропонувати нове (оновлене) бачення змісту, структури та основних завдань діяльності психологічної служби на найближчу перспективу у вигляді концепції психологічного супроводу освітніх реформ.

1. Актуальний стан розвитку психологічної служби у системі освіти

1.1. Розвиток мережі психологічної служби. Мережа закладів і підрозділів психологічної служби почала формуватися з часу створення власне самої служби (1991р.). Концептуальні засади розвитку мережі будувалися на розумінні необхідності забезпечити надійну методичну підтримку нечисленних тоді практичних психологів закладів освіти. Таку підтримку, на нашу думку, могли надати регіональні (обласні, міські, районні) методичні центри психологічної служби. Обласні центри пропонувалось створювати або на базі профільних кабінетів/лабораторій обласних інститутів післядипломної педагогічної освіти, або як окремі юридичні особи, що підпорядковуються обласним управлінням/департаментам науки і освіти та мають статус закладів комунальної власності. Районні/міські центри/кабінети психологічної служби створювались або на базі районних/міських методичних кабінетів, або як юридичні особи комунальної власності. За неможливості створення кабінету/центру в районі/місті у методичному кабінеті відповідного рівня вводилась посада методиста, який відповідав за психологічну службу (Панок, 2012).

З 2002 р. почалась активна співпраця центрів психологічної служби з обласними, районними, міськими психолого-медико-педагогічними консультаціями (ПМПК) відповідного рівня (Панок, 2012), що значно підвищило якість роботи з дітьми, які мають особливі освітні потреби.

Станом на 2016 р., за даними моніторингу (Горленко та ін., 2016), у всіх областях країни функціонували обласні центри психологічної служби, в яких працювали від 2 до 15 методистів. Загальна чисельність фахівців в обласних центрах становила близько 100 фахівців. Районних центрів налічувалось 18, міських - 23. Супровід професійної діяльності працівників психологічної служби на той час у країні здійснювали 782 методисти.

У 2016 р. почалась реформа децентралізації, у тому числі й управління освітою. У зв'язку з цим відбулися і відбуваються дотепер такі зміни:

- скорочення або повна ліквідація методичних кабінетів на рівні районів і міст;

- ліквідація ПМПК усіх рівнів і створення інклюзивно-ресурсних центрів (ІРЦ) на базі новостворених територіальних громад;

- уведення інклюзивних форм освіти дітей із особливими освітніми потребами, які розглядаються керівниками закладів освіти як один із напрямів роботи працівників психологічної служби.

Сьогодні, за даними МОН України (2019), спостерігається невелике збільшення кількості методистів психологічної служби, але зменшення кількості районних/міських центрів. Практики шукають нові організаційні форми науковометодичного супроводу діяльності практичних психологів і соціальних педагогів закладів освіти об'єднаних територіальних громад (ОТГ). Співробітники обласних центрів відзначають значне збільшення запитів від працівників служби, оскільки основна ланка методичного забезпечен- 
ня - районні/міські центри або методисти, фактично не функціонує.

Наступним кроком реформи освіти є ліквідація з 1 вересня 2020 р. районних/міських методичних кабінетів/центрів і створення натомість центрів професійного розвитку педагогічних працівників (проєкт) (МОН України, 2020). Чи буде передбачено у новій структурі роботу методистів або методичних відділів, які забезпечуватимуть діяльність психологів і соціальних педагогів закладів освіти, поки невідомо. У новому Законі України «Про повну загальну середню освіту» (2020) немає жодної згадки про діяльність психологічної служби, хоча це і суперечить основному Закону України «Про освіту» (2017).

1.2. Кадрове забезпечення психологічної служби. На кінець 2015-2016 навчального року кількість спеціалістів психологічної служби становила 22,6 тис. працівників. Із загальної чисельності фахівців - 14,8 тис. практичних психологів (57,3\% від нормативної потреби), 7,0 тис. соціальних педагогів $(48,4 \%)$ та 782 методиста (Горленко та ін., 2016).

За результатами аналізу даних із регіонів у 2018-2019 навчальному році кількість фахівців психологічної служби становила 23,0 тис. осіб, із них: практичні психологи - 15,0 тис., соціальні педагоги - 7,2 тис., методисти - 815 (MOH України, 2019)

За узагальненими даними (МОН України, 2019), у 2018-2019 н.р. забезпеченість практичними психологами та соціальними педагогами у закладах освіти сьогодні має тенденцію до зменшення посад практичних психологів на 9 осіб. Порівняно з попереднім навчальним роком кількість соціальних педагогів збільшилася на 113 осіб, методистів - на 48 фахівців. Загалом чисельність працівників психологічної служби збільшилася на 152 особи (МОН України, 2019).

У 2018-2019 н.р. забезпеченість практичними психологами у закладах освіти (у ставках) становила 11240,25 - 62,3\% від загальної потреби, соціальних педагогів - 5122,25 ставок, тобто 48,8\% (МОН України, 2019). Отже, середній показник від потреби наявних ставок становить $57,3 \%$.

Маємо зазначити, що на повну ставку працюють 6,7 тис. практичних психологів, на 0,75 ставки - 1,8 тис. осіб, на 0,5 ставки 4,9 тис., 0,25 ставки - 1,7 тис. осіб (МОН України, 2019). Серед соціальних педагогів, за даними
МОН України, на повну ставку працюють 2,8 тис. осіб, на 0,75 ставки - 954, на 0,5 ставки - 2,4 тис., 0,25 ставки - 1,0 тис. осіб (МОН України, 2019).

Можна зробити висновок, що кадрове забезпечення психологічної служби протягом останніх років залишається загалом стабільним. Найбільш забезпеченими $є$ такі типи закладів освіти: спеціальні освітні заклади; заклади, розташовані у великих містах; заклади зі статусом «гімназія» або «ліцей»; різні елітні, приватні та експериментальні заклади освіти. Найменш забезпеченими $\epsilon$ заклади освіти, розташовані у сільській/гірській місцевості; заклади з низькою наповнюваністю; заклади професійної (професійно-технічної), позашкільної та вищої освіти.

Серед причин такої ситуації найактуальнішими, за нашими дослідженнями (Електронна бібліотека НАПН України, n.d.), є:

- низький рівень фінансового і матеріального забезпечення фахівців психологічної служби, особливо - у сільських і гірських районах;

- нерозуміння або байдуже ставлення керівників різних рівнів управління освітою до проблем розвитку психологічної служби у регіонах та окремих закладах освіти;

- низький професійний рівень працівників психологічної служби, що обумовлено відсутністю спеціалізації і профілізації у післядипломній підготовці та методичній підтримці;

- неготовність випускників закладів вищої освіти відповідного профілю до практичної реалізації завдань діяльності психологічної служби у конкретному закладі освіти, що насамперед обумовлено невисоким рівнем викладання профільних дисциплін;

- відсутність належного методичного супроводу і супервізійної підтримки молодих спеціалістів.

1.3. Обсяги і зміст роботи фахівців психологічної служби. Незважаючи на значні складнощі, психологічна служба сьогодні здійснює великий обсяг роботи із психологічного і соціальнопедагогічного супроводу освітніх реформ, оперативно відгукується на соціальні проблеми, що виникають у нашому суспільстві загалом і в освіті зокрема (війна на Сході й окупація Криму, пандемія коронавірусу, переселення, перебудова мережі закладів освіти, ліквідація психологомедико-педагогічних консультацій, запровадження нових методик викладання тощо). Отже, спробуємо окреслити тільки деякі види роботи 
працівників психологічної служби, спираючись на власні дані та дані МОН України (2019).

Діагностика. Працівники служби у 20182019 н.р. провели 6,4 млн діагностичних обстежень учасників освітнього процесу, з яких індивідуальною діагностикою було охоплено 1,3 млн осіб, а саме: 977,6 тис. здобувачів освіти, 131,9 тис. педагогічних працівників і 198,9 тис. батьків, груповою формою психодіагностики було охоплено 5,0 млн осіб, а саме: здобувачів освіти - 4,1 млн особа, педагогічних працівників 401,5 тис. осіб, батьків - 504,6 тис. осіб (MOH України, 2019).

Профрілактика. Індивідуальними формами профілактичної роботи охоплено 549,9 тис. здобувачів освіти, 108,3 тис. педагогічних працівників і 202,2 тис. батьків; груповими формами профілактичної роботи - 2,6 млн. здобувачів освіти, 426,2 тис. педагогічних працівників і 609,3 тис. батьків (МОН України, 2019).

Мобінг, булінг, насильство. Працівники психологічної служби прийняли 48,6 тис. запитів від учасників освітнього процесу щодо протидії домашньому насильству. Зокрема, від батьків надійшло 15,1 тис., від педагогічних працівників - 12,8 тис., від дітей - 16,3 тис. та від інших зацікавлених осіб - 4,2 тис. звернень (MOH України, 2019).

Працівники психологічної служби прийняли 86,5 тис. запитів від учасників освітнього процесу щодо протидії булінгу (цькуванню) у закладах освіти. Зокрема, від батьків надійшло понад 27,7 тис. звернень, від педагогічних працівників - 23,1 тис., від дітей - 30,1 тис. та від інших зацікавлених осіб - близько 5,5 тис. звернень (МОН України, 2019).

Психологічна корекція. Індивідуальними формами корекційної роботи було охоплено 431,4 тис. здобувачів освіти, 22,3 тис. педагогічних працівників та 27,6 тис. батьків; груповими формами охоплено понад 3,0 млн здобувачів освіти, 45,7 тис. педагогічних працівників та 152,3 тис. батьків (МОН України, 2019).

Консультування. Індивідуальним і груповим консультуванням було охоплено понад 5,6 млн учасників освітнього процесу, де 3,4 млн осіб проконсультовано у груповій формі, а 2,1 млн респондентів - індивідуально (МОН України, 2019).

Просвітницька робота. Нею охоплено понад 3,3 млн здобувачів освіти, 787,4 тис. педагогів, 1,7 млн батьків (МОН України, 2019).
1.4. Науково-методичне забезпечення діяльності психологічної служби. Найбільш гострою проблемою у психологічній службі нині, на нашу думку, є проблема науково-методичного забезпечення професійної діяльності її працівників.

До недавнього часу методичне забезпечення діяльності працівників служби здійснювали через вертикально інтегровану систему районних/ міських/обласних центрів і методистів. Часто до співпраці в цьому питанні залучали професійні громадські організації, міжнародні фонди та інші організації, але все одно координація відбувалась через центри. Так застосовувались науково обґрунтовані методи психологічної діагностики і психологічної корекції для професійного розвитку фахівців.

Новий Порядок підвищення кваліфікації педагогічних і науково-педагогічних працівників (далі - Порядок) (Кабінет Міністрів України, 2019) спонукає до пошуку нових моделей науково-методичного супроводу працівників психологічної служби. Нагадаємо: згідно з Порядком кожен педагогічний працівник самостійно визначає зміст своєї післядипломної освіти і заклад, де це можна зробити. У такому разі виникає запитання: як орієнтувати психологів закладів освіти на виконання масштабних державних програм і проєктів? Як упроваджувати єдині методичні підходи до розв'язання типових освітніх проблем? Як здійснювати профілактичну чи психокорекційну роботу на певній території, коли вона, ймовірно, буде здійснена з застосуванням різних методик? Як порівнювати одержані результати? Ці та інші питання гостро постали перед керівни ками психологічної служби і зумовлюють сьогодні пошук найбільш оптимальних моделей методичного забезпечення ії працівників. Якщо відповідей не буде знайдено, психологічна служба розпадеться на окремі регіональні чи місцеві структури або окремих спеціалістів, які діють самі собою.

1.5. Матеріально-технічне забезпечення прачівників психологічної служби. Забезпеченість кабінетами практичних психологів закладів освіти загалом становить (МОН України, 2019): окреме приміщення - 56\%, суміщені приміщення 40\%, немає кабінету - 4\%. Зокрема, у Дніпропетровській області забезпеченість окремими кабінетами становить 78\%, у Київський - 70\%, а найнижчий відсоток - у Івано-Франківській (27\%) і Тернопільській (5\%) областях. 
Маємо зазначити, що показник забезпеченості кабінетами соціальних педагогів значно нижчий: окреме приміщення мають 36\%, суміщені 60\%, немає кабінету в 4\% осіб. Зокрема, у Дніпропетровській і Київській областях забезпеченість соціальних педагогів окремим кабінетом становить по 54\% і це найвищий показник (MOH України, 2019).

Водночас у Вінницькій, Львівській, Хмельницькій областях досить не погано працюють над тим, щоб забезпечити всіх фахівців кабінетами (100\%). Фахівці психологічної служби Волинської, Донецької, Дніпропетровської, Закарпатської Кіровоградської, Чернівецької областей і Києва також забезпечені на 99-98\%, незважаючи на те, що $€$ суміщені робочі місця. Забезпеченість кабінетами фахівців психологічної служби інших областей потребує покращення відповідно до чинних вимог (МОН України, 2019).

1.6. Підвищення кваліфікації і атестація фахівців психологічної служби. У свій час нами було визначено, що фахівець, який працює у закладі освіти, має один методичний день на тиждень (чотири на місяць). У багатьох центрах психологічної служби областей і міст Києва і Севастополя раз на місяць проводився «методичний день». Такі дні відбувались і в міських/районних центрах.

Найважливішою умовою планування роботи на районному та обласному рівнях був акцент на необхідності враховувати потребу у професійному розвиткові конкретного фахівця. Робота методичних об'єднань здійснювалась у різних формах: теоретичні семінари, наукові доповіді, повідомлення про досвід роботи, семінарипрактикуми, диспути-дискусії, ділові ігри тощо планувались зазвичай відповідно до запитів ії учасників і з огляду на реальне кадрове забезпечення та часовий вимір.

Консультації, супервізійні сесії, наставництво були складовою професійного розвитку фахівця, який здійснюється за індивідуальними планами з урахуванням його професійних потреб. Вони передбачали систематичне вивчення психологопедагогічної, наукової літератури, участь у методичних об'єднаннях, семінарах, конференціях. До колективних форм методичної роботи відносяться: районні (міські) методичні об'єднання, методичні оперативні наради, випуск методичних бюлетенів, рекомендацій науково-практичних конференцій, інформаційні повідомлення, практичні заняття, тренінги, диспути, ділові ігри, бесіди, семінари-практикуми, школи передового педагогічного досвіду, проблемні (інноваційні) групи. Останнім часом почали широко застосовуватись вебінари, інтернет-конференції, онлайнконсультування та інші форми дистанційної методичної роботи.

Сьогодні працівник служби має надати сертифікат або інший документ, що засвідчує проходження курсів підвищення кваліфікації, не менше як на 30 академічних годин на рік. Такі документи мають надавати організації, що мають ліцензії на підвищення кваліфікації. Інакше підвищення кваліфікації фахівців психологічної служби стає непередбачуваним і несистемним. Не виключено, що документ про підвищення кваліфікації можна буде просто купити. Більше того - зміст післядипломної освіти може бути ненауковим, містичним, міфологічним.

Атестація працівників психологічної служби нині помітно тяжіє до формальності і видається дуже суб'єктивною, оскільки працівник атестується у тому закладі, де він працює. Отже, працівни ка психологічної служби атестує директор школи комісія, що складається із учителів-колег. Це може призвести і подекуди вже призводить до дискредитації як окремих працівників, так і психологічної служби.

2. Суспільні та освітні реформи. Виклики і проблеми

Можемо констатувати, що сьогодні є низка проблем і чинників, які зумовлюють необхідність осучаснення психологічної служби для підвищення ефективності психологічного забезпечення освітніх реформ. Назвемо тільки основні напрями вдосконалення і умови, в яких необхідно буде діяти.

2.1. Концепція Нової української школи (МОН України, 2016) докорінно змінила бачення розвитку освіти в сучасному українському суспільстві. Передусім це суттєва зміна професійної позиції учителя в освітньому процесі, що передбачає зміну його ставлення до учнів, до змісту і форм навчального процесу, до оцінювання якості освіти, до батьків і колег. Наступний крок - зміна вимог до знань і життєвих компетенцій учнів. Глибоких змін потребує також і практика міжособистісного спілкування усіх учасників освітнього процесу, запровадження принципів відкритості, рівності, інклюзивності та партнерства.

2.2. Створення інклюзивно-ресурсних центрів для роботи з дітьми, які мають особливі освітні потреби, породило низку питань про функції і 
зміст діяльності працівників психологічної служби освітніх закладів. Іноді від працівників служби вимагають виконання функцій дефектолога або клінічного психолога, для чого необхідна підготовка зі спеціальної психології (за нозологіями).

2.3. Децентралізація. Зміни структури управління освітою в умовах децентралізації породили суперечності щодо розуміння підпорядкування працівників служби закладів освіти, яке викладено у Положенні про психологічну службу (MOH України, 2018). Психологи закладів освіти новостворених об'єднаних територіальних громад (ОТГ) іноді залишаються без належного методичного супроводу, поза межами процесу міжкурсової підготовки і атестації, без належної супервізії обласного і районних методичних центрів.

2.4.Проблема належного методичного забезпечення. Сьогодні методичне забезпечення працівника психологічної служби не можна назвати системним і науково обґрунтованим. У багатьох випадках методичний арсенал практичного психолога часто становлять випадкові, невалідні методики діагностичної і корекційнорозвиткової роботи. Не всі працівники служби мають хоча 6 перелік рекомендованого до застосування у практичній роботі інструментарію.

Найбільш показовим у методичному забезпеченні працівників психологічної служби є фактичний демонтаж усієї системи: районні/міські методичні служби майже повністю ліквідовані, методисти переведені або перейшли до ІРЦ чи у школи, практичні психологи та соціальні педагоги закладів освіти ОТГ вимушені звертатися напряму до обласних центрів, що значно перевантажило їх роботу.

2.5. Комерціалізація і професійна відповідальність. У багатьох випадках методичний інструментарій для працівників служби видається часто без належного науково-методичного рецензування, без відповідних грифів і експертизи. Різні видавництва та інші організації активно використовують доволі великий ринок, яким є сьогодні психологічна служба, для просування продуктів сумнівної якості (методики, журнали, сайти, тренінги, навчання і т.п.). Загалом позитивна тенденція до диверсифікації форм підвищення кваліфікації має зворотній бік - низьку якість змісту методичних матеріалів. Фактично ніхто не несе відповідальності за їх якість, отже, ніхто не має відповідальності перед клієнтами.

2.6. Проблема дотримання етичних норм $i$ професійних стандартів. Сьогодні доволі розпо- всюдженими є випадки, коли спеціалісти своїми діями дискредитують професію - беруться виконувати функції, що не відповідають професійним стандартам, розголошують інформацію про клієнта, ставляться до нього упереджено, застосовують непсихологічні методи (астрологію, нумерологію, соціоніку тощо), використовують психологічні методи на власну користь (зиск). Ця проблема є чи не найгострішою у психологічному супроводі освітніх реформ: немає комісії з професійної етики; психологічний інструментарій розробляється і запроваджується у практику без рецензування і належної експертизи; психологіч ну діяльність здійснюють особи, які не пройшли відповідного навчання чи підвищення кваліфікації; численні курси та тренінги проводять люди і організації, що не мають жодного відношення до психології чи методичних служб. Ці та інші порушення етичних норм не дістають належної оцінки від професійного співтовариства і правоохоронних органів.

2.7. Проблема професійної підготовки практичних психологів і соціальних педагогів у закладах вищої освіти. Вона, традиційно, залишається доволі гострою. Майбутні фахівці переважно просто не вміють спілкуватися із клієнтом, слухати його (точніше - чути), висловлювати і доносити свою думку, майже не мають навичок практичної роботи з клієнтами. Теоретична підготовка випускників $€$ несистематичною, почасти - еклектичною і не ґрунтується на чітких методологічних позиціях. Деякі випускники не знають класичних психологічних робіт Л.С. Виготського, Г.С. Костюка, С.Л. Рубінштейна. Тут також спостерігається проникнення в освітній процес закладів вищої освіти ненаукових, містичних концепцій і теорій.

Методична неузгодженість, відсутність системи ліцензування та фактична відсутність потужних професійних спілок знижують ефективність впливу представників нашої професії на усі сфери суспільного життя.

3. Візія, мета, стратегічні завдання діяльності психологічної служби

3.1. Бачення психологічної служби у системі освіmи

Візія (бачення). Психологічна служба є цілісною структурою, що забезпечує психологічний супровід і соціально-педагогічну підтримку всіх учасників освітнього процесу на основі єдиних стандартів, методик і технологій для реалізації 
основних завдань функціонування освітньої галузі.

Таке визначення бачення психологічної служби, з одного боку, нічим істотно не відрізняється від визначень інших служб - елементів системи освіти, з іншого боку, наголошує на сутнісних відмінностях психологічної служби від інших. Розглянемо це питання детальніше.

В освітній галузі існує кілька специфічних служб, які забезпечують їі функціонування і розвиток. Зокрема, це такі служби: фінансовоекономічна; юридична; методичного забезпечення; матеріально-технічного забезпечення та ін. Усі вони мають спільні ознаки: їх представники забезпечують виконання функцій служби на всіх рівнях управління освітою - міністерства, обласного департаменту, місцевого органу управління освітою і на рівні закладу освіти. Між різними рівнями цих служб є чітка, регламентована законами і підзаконними актами взаємодія і субординація (підпорядкування). Кожна служба виконує свої специфічні функції у забезпеченні функціонування освітньої галузі, застосовуючи свої специфічні методи і прийоми роботи.

Специфіка кожної служби полягає у застосуванні спеціальних прийомів і методів роботи, застосуванні єдиних узгоджених між собою методик і процедур. Специфіка психологічної служби з-поміж інших освітянських служб визначається метою і завданнями ії діяльності та специфічними методами, методиками і технологіями, що застосовуються фахівцями.

3.2. Мета діяльності психологічної служби з психологічного супроводу освітніх реформ

Основною метою діяльності психологічної служби системи освіти є підвищення ефективності освітнього процесу шляхом його індивідуалізації та, одночасно, захист психічного здоров'я і соціального благополуччя усіх його учасників на основі застосування наукових методів і технологій прикладної психології і соціальної педагогіки.

Психологічна служба системи освіти є складовою державної системи охорони фізичного і психічного здоров'я молодих громадян України і діє з метою виявлення і створення оптимальних соціально-психологічних умов для розвитку та саморозвитку особистості у процесі освіти.

Служба забезпечує своєчасне та систематичне вивчення психофізичного розвитку дитини, мотивів їі поведінки і діяльності з урахуванням вікових, інтелектуальних, фізичних, гендерних та інших індивідуальних особливостей, створення психологічних умов для саморозвитку та самовиховання, сприяє виконанню освітніх і виховних завдань закладами і установами освіти.

3.3. Cmратегічні завдання діяльності психологічної служби

Завдання діяльності психологічної служби системи освіти України полягають у:

- підвищенні ефективності освітнього процесу на основі практичного впровадження новітніх досягнень психологічної науки;

- захисті психічного здоров'я та особистісного суверенітету всіх учасників освітнього процесу;

- сприянні повноцінному особистісному й інтелектуальному зростанню дітей на кожному віковому етапі їх розвитку;

- створенні психологічних і соціальнопедагогічних умов для формування в учасників освітнього процесу мотивації до самовиховання і саморозвитку;

- забезпеченні індивідуального, особистісно орієнтованого підходу до кожної дитини на основі її всебічного психолого-педагогічного вивчення, практичного застосування філософії дитиноцентризму в освіті;

- профілактиці та корекції відхилень у соціальному, інтелектуальному і особистісному розвиткові учнів, студентів, вихованців;

- формуванні високого рівня психологічної культури всіх учасників освітнього процесу як на рівні знань і настанов, так і на рівні повсякденного спілкування у закладі освіти.

\section{4. Принципи діяльності}

Базові принципи організації психологічної служби:

Доступність психологічних і соціальнопедагогічних послуг для всіх учасників освітнього процесу закладу освіти. Цей принцип передбачає побудову таких організаційних моделей психологічної служби, які могли б забезпечити надання психологічної і соціально-педагогічної допомоги учням, студентам, батькам і педагогічним працівникам незалежно від віку, расової, релігійної або національної приналежності, майнового чи соціального статусу, місця проживання, типу закладу освіти, рівня розумового та фізичного розвитку.

Принцип науковості означає, що вся діяльність психологічної служби ґрунтується на основі наукових підходів, методологій і засадах наукової психології. Методи, методики і технології, що застосовують фахівці психологічної служби, мають бути науково обґрунтованими, валідними і 
надійними (Максименко, 2019; Панок та ін., 2006; Яценко, 2004). Неприпустимо застосування позанаукових, містичних, релігійних, окультних та інших методів і методик, що не пройшли наукової експертизи.

Принцип розвитку передбачає побудову усієї методології психологічного практикування на теорії розвитку особистості з урахуванням певних етапів, періодів, криз, епох. Найбільш продуктивною для цього $є$ теорія Л.С. Виготського, яка, крім усього іншого, має високий прогностичний потенціал.

Трактування цього принципу торкається також і розвитку структури психологічної служби як служби психологічного супроводу, яка має забезпечувати доступність своїх послуг усім учасникам освітнього процесу незалежно від віку, статі, соціальної чи національної приналежності, місця проживання чи етнокультурних особливостей.

Принцип комплексності і системності у наданні соціальної і психологічної допомоги означає, що в діяльності психологічної служби мають бути поєднані вузька спеціалізація із певною універсальністю спеціалістів. Поєднання у єдиному технологічному процесі універсальності зі спеціалізацією фахівців забезпечить, на нашу думку, реалізацію завдань діяльності психологічної служби загалом.

Міждисциплінарність у наданні психологічної і соціально-педагогічної допомоги означає, що у методиках і технологіях організації соціального і психологічного супроводу учасників освітнього процесу мають бути поєднані не тільки психологічні і соціально-педагогічні методи, а й методи інших суміжних наук: соціології, педагогіки, дефектології, дидактики, фізіології та ін.

Структурність і цілісність. Цей принцип передбачає функціонування в освітній галузі єдиної психологічної служби з чіткою структурою, підпорядкуванням і координацією взаємодії окремих її елементів. Він не суперечить різноваріантності організаційних форм служби на місцях, але власне конституює службу як єдину систему, що має єдину мету і завдання, методи і підходи до надання психологічної допомоги і здатна реалізувати великі галузеві проєкти з психологічної підтримки реформування освіти.

Принцип забезпечення професійної підтримки і допомоги спеціалістам психологічної служби. Структурно і функціонально психологічна служба має бути вибудувана так, щоб кожен окремий фахівець відчував методичну підтримку і психологічну допомогу, чи то у вигляді супервізії або інтервізії, чи то у вигляді навчальних семінарів і тренінгів. Важливою формою професійної підтримки $€$ методичні об'єднання спеціалістів служби за окремими напрямами роботи.

3.5. Основні види діяльності психологічної служби системи освіти:

- діагностика - психологічне обстеження здобувачів освіти, їхніх груп і колективів, моніторинг змісту й умов індивідуального розвитку молоді, своєчасне виявлення причин та особистісних проблем, що ускладнюють їх розвиток та освіту;

- корекція - здійснення психологопедагогічних заходів для усунення відхилень у психофізичному, особистісному та соціальному розвиткові і поведінці, схильності до залежностей та правопорушень, подолання різних форм девіантної поведінки, формування соціально корисної життєвої перспективи;

- реабілітація (адаптація, реадаптація) надання психолого-педагогічної допомоги дітям, підліткам, молоді, які перебувають у кризовій або складній життєвій ситуації для соціальнопсихологічної адаптації та повернення до звичайних умов навчання і життєдіяльності в соціумі;

- профілактика - своєчасне запобігання відхиленням у психофізичному розвиткові та становленні особистості, міжособистісних стосунках, конфліктним ситуаціям в освітньому процесі тощо:

- прогностика - розроблення, апробація i застосування моделей поведінки групи та особистості у різних умовах і життєвих ситуаціях, визначення тенденцій розвитку груп, міжгрупових взаємин та освітньої ситуації у регіоні, надання методичної допомоги педагогам і батькам у прогнозуванні та побудові найбільш сприятливих трендів індивідуального і групового розвитку;

- проєктування - визначення змісту, напрямів і психолого-педагогічних методів стимулювання індивідуального розвитку учнів і студентів, їхніх груп і колективів, складання на цій основі життєвих планів, проєктів розвитку колективу і груп.

3.6. Система надання психологічних послуг учасникам освітнього процесу в умовах децентралізації і ії методичне забезпечення

В умовах децентралізації надання психологічних послуг учасникам освітнього процесу видається найбільш ефективним на двох рівнях: первинному і вторинному. Первинний рівень 
забезпечує психологічна служба закладу освіти, вторинний - центри професійного розвитку педагогічних працівників або методкабінети, навчально-методичні центри психологічної служби, методисти-супервізори, ІРЦ. Так відбувається надання психологічних послуг усім учасникам освітнього процесу, а також поглибленої і спеціалізованої допомоги в окремих складних випадках і методичної підтримки професіоналам, які працюють на первинному рівні.

Не первинному рівні в основному здійснюється: проведення скринінгів і моніторингів стану і рівнів особистісного, індивідуально-психологічного та соціального розвитку учнівських і педагогічних колективів, окремих учасників освітнього процесу, виявлення найбільш гострих проблем у розвиткові та взаєминах; проведення первинної профілактики; психологічна просвіта і консультування; забезпечення соціально-психологічної і педагогічної реабілітації (адаптації, реадаптації); реалізація програм соціальної і психологічної корекції для окремих учасників, груп і колективів; психологічне забезпечення та участь у проєктуванні життєвих і професійних перспектив здобувачів освіти та трендів розвитку їх колективів.

На вторинному рівні надання психологічної допомоги забезпечуються: поглиблена психологічна діагностика і прогнозування індивідуальнопсихологічного, особистісного і соціального розвитку окремих представників або учнівських груп і колективів; соціально-психологічна реабілітація (індивідуальна і групова) окремих складних випадків; психологічна і соціально-педагогічна корекція особистісних і соціальних відхилень у розвиткові і міжособистісних взаєминах; робота 3 іншими складними випадками та побудова соціально корисних життєвих перспектив.

Методичну підтримку фахівцям первинного рівня можуть надавати фахівці зі вторинного рівня психологічної допомоги, які в основному $\epsilon$ психологами вищої категорії або психологамиметодистами. Останні можуть виконувати функції супервізії, керівництва методичних об'єднань (за конкретною проблематикою) або експертів із конкретних питань.

Науково-методичне забезпечення. Система науково-методичного забезпечення діяльності психологічної служби вбачається диверсифікованою. До цього забезпечення можуть долучатися різного роду установи і організації - ОІППО, університети, установи Національної академії педагогічних наук України, професійні громадські організації та ін. Важливо відзначити обов'язкове проведення науково-методичної експертизи методів і методик, що пропонуються до застосування, Українським науково-методичним центром практичної психології і соціальної роботи та відповідним відділом Інституту модернізації змісту освіти МОН України або окремою експертною радою.

\section{7. Атестація і ліцензування працівників}

Атестація працівників психологічної служби відбувається відповідно до процедур і нормативів, затверджених МОН України, з єдиним застереженням: до атестаційної комісії має бути включений хоча б один представник служби (методист методичного (сервісного) центру, психолог-супервізор, керівник психологічної служби). При цьому атестаційній комісії надається експертний висновок про роботу апліканта (того, хто атестується), підписаний психологомметодистом або психологом-супервізором, або керівником психологічної служби, який добре ознайомлений із роботою апліканта.

Для ліщензування фахівців психологічної служби при обласних департаментах освіти і науки на базі обласних центрів створюються спеціальні ліцензійні комісії. Ліцензування відбувається за такими напрямами: «первинна допомога», «вторинна допомога (за напрямами)», «супервізія (за напрямами)».

Процес ліцензування відбувається у два етапи: складання професійних письмових тестів і співбесіди з ліцензійною комісією за наявності позитивних відгуків з місця роботи та від супервізора.

Напрям «первинна допомога» передбачає ліцензування фахівців психологічної служби, які пройшли курси підвищення кваліфікації за напрямом «первинна допомога», відпрацювали під супервізією не менше трьох років і мають позитивний висновок від супервізора.

Орієнтовний список знань, умінь і компетентностей: уміння слухати і чути співрозмовника; уміння говорити - доносити свою думку до свідомості клієнтів різного віку, статі, національності, рівня освіти і культури, професії і т.п.; знання основ прикладної психології і соціальної педагогіки; знання і дотримання вимог професійної етики; навички первинного консультування; навички публічного виступу перед різними аудиторіями; навички організації і проведення групової роботи; навички і методики проведення скринінгів і моніторингів; основи прикладної психодіагностики; уміння готувати висновки 
психодіагностичного чи соціально-педагогічного обстеження; знання нормативних документів психологічної служби; володіння методами і методиками первинного обстеження (за окремим списком); знання законів групової динаміки і основ соціальної психології малих груп; знання і дотримання вимог професійної етики і професійних стандартів.

Напрям «вторинна допомога (за напрямами)» передбачає ліцензування фахівців психологічної служби, які мають ліцензію «первинна психологічна допомога», пройшли курси підвищення кваліфікації за окремим напрямом вторинної допомоги, відпрацювали під супервізією не менше двох років і мають позитивний висновок від супервізора.

У цьому випадку ліцензуються знання і навички працівників служби застосовувати конкретну методику психодіагностики, психотерапії, психологічної корекції для конкретної цільової аудиторії що, власне, і засвідчує ліцензійний документ.

Ліцензування у напрямі «супервізія (за напрямами)» передбачає наявність: двох перших типів ліцензій; досвіду роботи за другим напрямом ліцензування не менше двох років; підвищення кваліфікації як майбутнього супервізора за тим же напрямом, що і ліцензія вторинної допомоги; висновку супервізора.

Ліцензійна комісія має право позбавити працівника служби ліцензії за заявою юридичної чи фізичної особи після ґрунтовного персонального розгляду справи. Позбавлення ліцензії $\epsilon$ фактично позбавленням права на виконання функцій, зазначених у ліцензії. Відновлення ліцензії відбувається у такий самий спосіб, як і її здобуття.

4. Методи, інструменти і шляхи реалізації стратегічних завдань

4.1. Науково-психологічне забезпечення освітніх ресрорм

В умовах сьогодення психологічна практика гостро потребує науково-психологічного забезпечення своєї діяльності. Не випадкових і невалідизованих психодіагностичних і психокорекційних методик, а науково обґрунтованих і надійних щодо одержання достовірних результатів, які становлять не випадковий набір, а систему, що грунтується на міцній наукові методології. Нині практика у застосуванні інструментарію виходить далеко за межі наукової методології, скидаючись на гадання, екстрасенсорику, ворожіння та парапсихологію, розмиваючи тим самим основи психології як наукової дисципліни. Повернути практичну психологію у межі власне психології може тільки психологічна наука. Отже, ефективне психологічне забезпечення освітніх реформ $\epsilon$ можливим тільки і винятково на засадах наукової психології. Далі ми зробимо спробу окреслити основні напрями науково-психологічного супроводу реформування освітньої галузі.

Перше завдання - це формування методологічних основ психологічної практики - розвиток прикладної психології (Панок, 2017). Наука може собі дозволити поліметодологічні підходи або навіть еклектику в цьому питанні. Психологічна практика має базуватися на єдиній методології, оскільки у протилежному випадку психологи просто будуть не розуміти один одного. Найбільш адекватною тут може бути методологія синтезу (Л.С. Виготський). Саме синтез як єдина методологія дає змогу цілісно і найбільш адекватно відобразити сутність психічних явищ у психологічній практиці (Панок, 2019).

Друга група проблем, що потребують нагального розв'язання - це теорії психологічної практики. Теоретичне розмаїття у науковій психології - закономірний процес, що відображає драматургію наукового пізнання (Максименко, 2019; Панок, 2017; Рибалка, 2017; Яценко, 2004). Водночас ця теоретична поліфонія не може бути перенесена безпосередньо з науки у практику. Психологічна практика для методичного забезпечення своєї діяльності та професійної підготовки спеціалістів-психологів вимагає побудови єдиної, цілісної, системної, внутрішньо несуперечливої метатеорії. Тобто такої системи поглядів на предмет професійної діяльності, яка не $\epsilon$ внутрішньо суперечливою, здатна об'єднати найбільш відомі та опрацьовані часткові психологічні теорії.

Третім аспектом науково-психологічного забезпечення освітніх реформ $€$ пріоритетний розвиток прикладної психології. Наукова психологія забезпечує методологічний розвиток i, власне, формування методичних основ прикладної психології. Зокрема, мають бути здійснені: наукова експертиза існуючих методів, методик і технологій, які застосовуються у психологічній практиці (а перед цим - розроблення процедур такої експертизи); розроблення структури методів (процедур) створення методик, методів і технологій професійної діяльності психологівпрактиків; розроблення методології оцінки ефективності окремих методів і напрямів психо- 
логічного практикування - психологічне консультування, прикладна психодіагностика, психологічна корекція, психотерапія тощо.

Окремою, надзвичайно актуальною сьогодні, $€$ проблема професійної підготовки і підвищення кваліфікації практикуючих психологів у закладах вищої освіти. Серед пріоритетів тут не тільки формування системи знань, умінь і компетентностей майбутнього фахівця, а й професійно важливих рис його особистості та чітких етичних професійних переконань. 3 огляду на викладені вимоги, система підготовки майбутніх психологівпрактиків у закладах вищої освіти потребує докорінної перебудови, починаючи зі стандартів і закінчуючи методиками проходження виробничої практики студентами.

Повертаючись до конкретних практичних проблем науково-психологічного забезпечення освітніх реформ, які тим не менше безпосередньо пов'язані з проблемами методології і теорії, необхідно вказати на кілька основних і нагальних.

Найважливішим, на нашу думку, є визначення норм вікового розвитку особистості здобувача освіти хоча б від 5-6 до 16-17 років. Тут мінімально необхідними мають бути норми розвитку основних психічних процесів - пам'яті, уваги, рівня інтелекту, уявлень про оточуючий світ і самого себе, швидкості мисленнєвих функцій; рівня та специфіки особистісного розвитку самооцінки, ціннісних та соціальних орієнтацій, нахилів та інтересів, уявлення про рольову поведінку, навички спілкування, саморегуляцію; рівня соціального розвитку - уявлення про соціальні зв'язки між людьми, соціальними інституціями загалом і школою зокрема. Ці норми мають бути узгоджені 3 індивідуальнопсихологічними, гендерними, етнічними та іншими особливостями, а також умовами сімейного виховання і особливостями життєвого шляху, наслідками впливу інформаційнокомунікативних технологій. Особливу увагу необхідно приділити відхиленням від норми, які можуть виникнути внаслідок неадекватного виховання або відхилень у фізичному чи психічному здоров'ї.

Визначення норм вікового розвитку (психічного, особистісного і соціального) тісно пов'язано із вибором інструментів його дослідження (діагностики). Першою і головною умовою тут має бути валідизація або ревалідизація цих інструментів - тестів, опитувальників, скринінгових методик тощо. Наступним кроком - відбір і обґрунтування найбільш ефективних і простих у застосуванні психодіагностичних методик для застосування їх у повсякденній психологічній практиці. У результаті практичний психолог має одержати набір інструментів для здійснення прикладної психодіагностики. Звершенням роботи у цьому напрямі, на нашу думку, стає розроблення навчальних програм для професійної підготовки, підвищення кваліфікації і ліцензування практичних психологів.

Ще більш важливою і не менш об'ємною має бути робота з верифікації численних психологічних, розвиткових, корекційних чи терапевтичних практик (методик). Основою верифікації можуть бути такі ймовірні критерії: відсутність явної або прихованої шкоди для психічного чи фізичного здоров'я клієнта від застосування тієї чи іншої методики або методичного прийому; відповідність методики чи прийому віковим, гендерним, індивідуально-психологічним, особистісним і соціальним особливостям клієнта; безумовне дотримання норм професійної етики на усіх етапах надання психологічної допомоги із застосуванням конкретної методики. Результатом верифікації $€$ рекомендації до застосування відібраних (рекомендованих) методик і методичних прийомів з обов'язковим описом меж їх застосування та можливими негативними наслідками у разі непрофесійного застосування або недотримання умов методики.

У результаті багатопланової і доволі тривалої, як на наш розсуд, роботи науковців ми маємо одержати стандартні протоколи професійної діяльності практичного психолога. Протокол у цьому випадку - це документ, який містить чітку і систематизовану послідовність дій і алгоритмів застосування стандартних психодіагностичних, психопрофілактичних і психокорекційних методів і методик, спрямованих на розв'язання типових проблем клієнта, який перебуває у типовій життєвій ситуації. Безперечно основою для розроблення протоколів мають стати: одна 3 теорій вікового розвитку особистості (на нашу думку, це теорія Л.С. Виготського і його послідовників) (Панок, 2019); циклограма діяльності практичного психолога, яка узгоджується 3 циклограмою роботи закладу освіти (Горленко та ін., 2017); перелік затверджених і валідних методів і методик прикладної психодіагностики, психологічної профілактики, психологічної корекції, соціально-психологічної реабілітації, психологічного прогнозування і психологічної просвіти. 
Тут зазначимо, що перші кроки у цьому напрямі вже здійснюються (Горленко та ін., 2018).

Отже, конструюючи єдину методологію і єдину теорію, наукова психологія самореалізується у психологічній технології, породжуючи прикладну психологію. I це, на нашу думку, є її найближчим актуальним завданням.

4.2. Оновлення нормативної бази діяльності психологічної служби

Першорядним кроком в оновленні нормативної бази має стати обговорення і прийняття концепції реформування психологічної служби, де будуть визначені ії засадничі підвалини місія, мета, стратегічні завдання, зміст і основні напрями роботи, види діяльності та організаційна структура, вимоги до методичного забезпечення і етичні вимоги до роботи спеціалістів. Перед тим, як створювати нові документи, необхідно провести інвентаризацію вже існуючих і за результатами такої роботи визначити: які документи необхідно розробити наново; які нормативні документи взяти за основу і вдосконалити відповідно до існуючих потреб і умов роботи; які документи можуть бути залишені без змін.

Не потребують глибокого оновлення, на нашу думку, Положення про кабінет працівника психологічної служби у закладі освіти, Нормативи розподілу робочого часу працівників психологічної служби та деякі інші.

Беззаперечно істотного оновлення потребує діюче нині Положення про психологічну службу у системі освіти України (МОН України, 2018). У ньому має бути представлено нову модель (або моделі) науково-методичного супроводу (керівництва) психологічною службою в умовах децентралізації. Також потрібно прописати систему методичної підтримки працівників служби в нових умовах.

Для забезпечення єдиних стандартів і нормативів роботи практичних психологів і соціальних педагогів необхідно запропонувати кілька новацій. Серед них: дворівнева модель психологічного супроводу всіх учасників освітнього процесу; запровадження циклограм діяльності працівників психологічної служби у всіх типах закладів освіти; запровадження протоколів (алгоритмів) роботи працівника служби у типових випадках; система методичної підтримки працівників служби включно з наставництвом і супервізією; наукова експертиза психологічного, соціально-педагогічного і соціологічного інструментарію, що застосовується у системі освіти; створення дорадчо- координаційного органу з керівництва психологічною службою; запровадження процедур атестації і ліцензування працівників психологічної служби. Ці та, можливо, інші новації, мають бути включені до нового положення і детально зазначені у окремих нормативних документах.

4.3. Запровадження дворівневої моделі психологічного супроводу

Дворівнева модель соціально-педагогічного і психологічного забезпечення реформування освіти, що описана вище, видається найбільш ефективною в сучасних умовах. Проте приваблива ідея потребує чіткого уявлення про шляхи і засоби своєї практичної реалізації. Тут необхідно розглянути організаційні, науково-методичні та нормативні аспекти.

Серед нормативних заходів першим кроком має бути опис дворівневої моделі у новому положенні про психологічну службу в загальних рисах. Наступний крок - внесення доповнень у Типове положення про атестацію педагогічних працівників (МОН України, 2010). Принагідно зазначимо, що це положення варто доповнити й іншими новаціями, що стосуються специфіки діяльности психологічної служби і її працівників. Далі - розроблення положення про ліцензування працівників психологічної служби, у якому необхідно чітко охарактеризувати ліцензійні вимоги і сам процес ліцензування, що, очевидно, має складатися з теоретичної і практичної частин, розгляду експертних висновків, відгуку супервізора та співбесіди.

Науково-методичні аспекти запровадження такої моделі передбачають насамперед визначення змісту й професійного рівня виконання трудових функцій на різних рівнях надання психологічної і соціально-педагогічної допомоги. Після висвітлення цих функцій необхідно з'ясувати критерії їх оцінювання щодо кожного спеціаліста, який атестується. Завершальним кроком буде встановлення необхідної і достатньої суми балів для атестації.

Окрім того, важливо прописати сам процес атестації, розробити перелік і зміст теоретичних завдань і тестів, структуру і критерії експертних висновків і відгуку супервізора. Вагомим також $\epsilon$ розроблення списку першоджерел, які має обов'язково вивчити кандидат для складання теоретичної частини. Це питання, на нашу думку, $\epsilon$ ключовим для формування теоретичної узгодженості і теоретико-методологічної бази психологічної служби як цілісної системи. 
Проведення такої роботи дасть змогу розробляти нові або вносити зміни в існуючі стандарти вищої та післядипломної освіти, створювати нові навчальні плани і програми, визначати якість професійної підготовки тощо. Іншими словами з'являється нагода для створення багатьох різноманітних курсів, спецкурсів, тренінгів та інших форм навчання які, тим не менш, чітко узгоджуються із загальною концепцією професійної підготовки фахівців і працюють на реалізацію державної освітньої політики у цьому аспекті.

Тут необхідно зробити одне важливе зауваження: у процесі розроблення критеріїв атестації фахівців, які забезпечують надання допомоги на другому, більш спеціалізованому рівні, необхідно визначити перелік їхніх функцій або основних напрямів надання психологічної і соціальнопедагогічної допомоги на цьому рівні. Найбільш ймовірними видаються два напрями науковометодичного пошуку: або піти за формальними ознаками - психодіагностика, соціально-психологічна корекція тощо, або за змістовними ознаками (проблемами клієнта) - психологічна корекція девіантної поведінки, психодіагностика складнощів у навчанні й ін. Очевидно, це питання - предмет подальшої дискусії.

Водночас чітка взаємодія первинної і вторинної ланок психологічної служби може значно підвищити ефективність роботи, забезпечити взаємозамінність фахівців та підвищити якість методичної підтримки і професійного розвитку працівників психологічної служби.

4.4. Циклограми діяльності працівників служби

Одним із основних заходів, що допоможуть зберегти методичну єдність психологічної служби та скоординованість ії дій на регіональному і всеукраїнському рівнях, $€$ запровадження типових циклограм діяльності працівників - практичних психологів і соціальних педагогів.

Особливої уваги у розробленні циклограми діяльності працівника заслуговує проблема щодо врахування структури освітнього процесу в конкретному освітньому закладі та основних психолого-педагогічних вимог до здійснення цього процесу. Є заклади освіти різних типів, різних рівнів освіти, різного профілю. Відповідно і циклограми, з одного боку, мають бути типовими, тобто базуватися на загальнопедагогічних підходах, принципах і методах. 3 іншого боку відповідати специфіці закладу освіти та враховувати його особливості. Важливо також при застосуванні типових циклограм у практичній діяльності зважати і на контингент учнів та специфіку викладацької діяльності.

Типовий річний цикл діяльності освітнього закладу покладено в основу розроблених нами раніше циклограм діяльності працівників психологічної служби (Горленко та ін., 2017). Циклограма $€$ основою планування роботи працівника служби на навчальний рік та водночас - основою звітності. Для якнайповнішого врахування специфіки закладу освіти, особливостей контингенту здобувачів освіти та педагогічної і батьківської громадськості, професійних навичок і умінь самого працівника служби в циклограмі передбачено близько 50\% часу для інших видів роботи, які має здійснювати працівник служби. Фактично виходить, що половину робочого часу працівника служби регламентовано циклограмою, а половину - запитами учасників освітнього процесу та його власною ініціативою.

4.5. Протоколи (алгоритми) діяльності прачівників

Наступним засобом забезпечення методичної єдності психологічної служби ми вважаємо створення і застосування протоколів роботи працівників служби. Протокол, у нашому розумінні, - це затверджений порядок дій працівника служби у типовій професійній ситуації для розв'язання типових проблем роботи з клієнтами. Порядок дій, про який йдеться, передбачає чіткий і усталений алгоритм, послідовність операцій, що дає змогу надавати кваліфіковану допомогу певній категорії учасників освітнього процесу (цільовій групі) і може бути основою для оцінки ефективності роботи фахівця, його кваліфікації та дотримання професійних стандартів (Панок, 2012; Панок, 2017).

Запровадження протоколів дасть підстави для оптимізації професійної підготовки та підвищення кваліфікації фахівців у закладах вищої і післядипломної освіти, а також вироблення більш чітких і конкретних критеріїв оцінювання якості надання послуг практичними психологами і соціальними педагогами.

4.6. Координаційна рада з забезпечення діяльності психологічної служби

Багаторічний досвід керівництва психологічною службою у нині існуючий парадигмі показав, що така система керівництва в сучасних умовах освітніх реформ стає все менш і менш ефективною. Численні кадрові перестановки в департаментах і управліннях освітою, нерозуміння 
окремими начальниками суті і смислу психологічного супроводу освіти, суб'єктивізм прийнятих рішень, випадковий підбір малокваліфікованих кадрів, зокрема й у самій службі, призводять до численних проблем - від незрозумілого і хаотичного методичного забезпечення працівників до дезінтеграції методичних структур і зниження авторитету служби в очах педагогічної громадськості.

Для усунення цих та інших недоліків і підвищення ефективності служби загалом необхідно створити при МОН України координаційну раду психологічної служби, до якої мали б бути обрані авторитетні керівники регіональних психологічних служб, науковці та викладачі інститутів післядипломної педагогічної освіти, представни ки професійних громадських організацій.

Головним завданням координаційної ради має бути визначення стратегії розвитку служби, шляхів її розвитку в середньостроковій і довгостроковій перспективі, проведення моніторингів розвитку і змісту діяльності окремих їі структур, аналіз першоджерел проблем розвитку і визначення шляхів та інструментів їх розв'язання, розгляд проєктів нормативних документів $\mathrm{MOH}$ України, що стосуються психологічної служби. Рада повинна мати повноваження заслуховувати найбільш важливі питання розвитку служби і пропонувати міністерству проєкти нормативних документів у межах своєї компетенції. Повноваження ради визначаються положенням про ії діяльність.

4.7. Єәина інформаційна система психологічної служби

Ідея про створення єдиної інформаційної системи психологічної служби (ЄІСПС) не $є$ новою (Панок та ін., 2006), але зараз вона видається найбільш актуальною. На нашу думку, вона має складатися з кількох підсистем, а саме: банку психодіагностичних методик; банку технологій або корекційно-розвивальних методик, які можуть бути представлені у вигляді протоколів роботи працівників служби; системи збору і збереження статистичних даних про кількість працівників психологічної служби, обсяг і види їхньої роботи, проблеми, з якими доводиться стикатися; даних про результати моніторингів і скринінгів, що були проведені на регіональному або всеукраїнському рівнях; інформації про установи і організації, що надають методичну підтримку працівникам служби. Зберігання і обробка нової інформації має відбуватися на кількох рівнях: користувача; ОТГ/району; області та на всеукраїнському рівні.

Запровадження такої системи дасть змогу:

- застосовувати стандартні методики і тести для здійснення психодіагностики і обстеження учасників освітнього процесу;

- здійснювати кваліфіковану обробку результатів тестування, моніторингів і скринінгів;

- порівнювати результати подібних обстежень у різних фахівців і представників цільових груп;

- професійно застосовувати протоколи корекційно-розвиткової роботи;

- об'єктивно оцінювати рівень кваліфікації і професійної підготовки працівників психологічної служби;

- одержувати достовірну статистичну інформацію про обсяги роботи працівників служби, їх кількість, професійний рівень, забезпеченість кабінетами і методичними засобами тощо;

- одержувати онлайн-консультації і методичну підтримку найбільш кваліфікованих фахівців.

Так, запровадження ЄІСПС $€$ не просто побажанням, а умовою збереження психологічної служби як єдиної системи та успішного подальшого її розвитку для повноцінного та ефективного психологічного супроводу освітніх реформ.

4.8. Підвищення престижності роботи працівників психологічної служби

Ефективність роботи працівників психологічної служби безпосередньо пов'язана з визнанням важливості та необхідності такої роботи суспільством, державою, педагогічною громадськістю.

Факторами, що негативно впливають на престижність роботи працівників психологічної служби у закладах освіти, на нашу думку, є:

- невисокий рівень оплати праці при значному і різнобічному навантаженні;

- нерозуміння учасниками освітнього процесу адміністрацією, педагогами, батьками, місця і ролі працівника психологічної служби в освітньому процесі;

- висунення різноманітних, часто суперечливих, вимог до змісту і результатів роботи фахівця;

- неконкретна, через нерозуміння і невисокий рівень підготовки, професійна позиція працівника психологічної служби або її відсутність узагалі;

- невисокий рівень освіти і професійної підготовки працівників, відсутність чіткої методичної позиції;

- низька практична готовність до виконання своїх посадових обов'язків, несформованість 
професійно важливих особистісних рис, професійних умінь і навичок.

Шляхами підвищення престижності роботи працівника психологічної служби у закладі освіти можуть бути:

- істотний перегляд змісту і форм професійної підготовки практичних психологів у профільних закладах вищої освіти з акцентом на формуванні професійно важливих навичок, умінь і якостей особистості;

- запровадження протягом перших трьох років роботи інтернатури з прикріпленням персонального супервізора та розробленням і виконанням індивідуальної програми набуття/підвищення кваліфікації (1 рік роботи - приблизно 1440 год.; з роки - 4300 год.);

- запровадження просвітницької роботи для усіх учасників освітнього процесу, зокрема й адміністрації закладу, щодо змісту, умов і результатів діяльності фахівців психологічної служби як обов'язкового елементу планування і звітності;

- підвищення оплати праці фахівцям психологічної служби, зокрема через доплати «за складність і напруженість», «за роботу в складних умовах» тощо;

- запровадження на державному/галузевому рівні свята «День психолога 23 квітня», який і так відзначається неформально.

Наостанок зауважимо: підвищення престижності професії практичного психолога і соціального педагога - відповідальність кожного спеціаліста.

\section{Висновки}

1. Аналіз проблеми дає змогу констатувати актуальність внесення певних змін до стратегічних документів, що визначають діяльність психологічної служби у системі освіти. Зокрема, сформульовано необхідність наступності у розвиткові служби та ідентифіковано виклики і небезпеки, які існують зараз у ії діяльності.

2. Запропоновано авторське бачення змісту оновлення психологічної служби. Головною тезою є розуміння служби як єдиної, цілісної структури, що забезпечує психологічний супровіо усіх учасників освітнього процесу, має єдину мету і завдання своєї діяльності, застосовує науково обгрунтовані методи надання соціальнопедагогічної і психологічної допомоги та забезпечує психологічну підтримку освітніх реформ.

Подальшого вивчення потребують питання узгодження єдиних протоколів діяльності практичних психологів і соціальних педагогів, визначення типових циклограм і діагностичних мінімумів, уточнення і апробація організаційних моментів, ліцензування діяльності та ін.

Підбиваючи підсумки, зауважимо, що викладений матеріал - лише початок дискусії про шляхи і методи вдосконалення психологічної служби як інструменту психологічного забезпечення процесу реформування освіти. Було б дуже важливо, щоб до цієї дискусії долучилося якомога більше науковців, викладачів, практиків-освітян і управлінців. Попри певну кількість невизначеностей і проблем, сьогодні зрозуміло одне - без належного психологічного забезпечення реалізація реформування освіти буде менш ефективною. Тому вдосконалення психологічної служби, якій майже тридцять років, є найважливішою відповідальністю професіоналів-психологів.

\section{СПИСОК ВИКОРИСТАНИХ ДЖЕРЕЛ}

Горленко, В.М., Луценко, Ю.А., Острова, В.Д., Сосновенко, Н.В., \& Ткачук, І.І. (2017). Методичні рекомендації щодо впровадження циклограм діяльності працівників психологічної служби (В.Г. Панок, ред.). Київ: УНМЦ практичної психології і соціальної роботи. https://lib.iitta.gov.ua/709623/

Горленко, В.М., Острова, В.Д., Сосновенко, Н.В., \& Ткачук, І.І. (2018). Застосування діагностичних мінімумів в діяльності працівників психологічної служби : методичні рекомендації (В.Г. Панок, ред.) Київ: УнМЦ практичної психології і соціальної роботи. https://lib.iitta.gov.ua/713246/

Горленко, В.М., Лунченко, Н.В., Мельник, А.А., Обухівська, А.Г., Панок, В.Г., \& Якимчук, Г.В. (2016). Статистичний бюлетень показників розвитку психологічної служби та психолого-медикопедагогічних консультацій за 2015-2016 навчальний рік. Київ: УНМЦ практичної психології і соціальної роботи. https://lib.iitta.gov.ua/705154/

Електронна бібліотека НАПН України. (n.d.). Український науково-методичний центр практичної психології і соціальної роботи. Лабораторія прикладної психології освіти. https:// lib.iitta.gov.ua/view/divisions/lape/

Закон України «Про освіту». (2017, 5 вересня). https:// zakon.rada.gov.ua/laws/show/2145-19

Закон України «Про повну загальну середню освіту». (2020, 16 січня). https://zakon.rada.gov.ua/laws/ show/463-20

Кабінет Міністрів України. (2019, 21 серпня). Деякі питання підвищення кваліфікації педагогічних і науково-педагогічних працівників (800). https:// zakon.rada.gov.ua/laws/show/800-2019-п

Кремень, В.Г. (2008). Філософрія людиночентризму в стратегіях освітнього простору. Київ: Педагогічна думка.

Максименко, С.Д. (2019). Теоретико-методологічні засади розвитку психологічної науки XXI сторіччя. Проблеми сучасної психології, (1), 7-16. https:// doi.org/10.26661/2310-4368-2019-1-15-01

Міністерство освіти і науки України. (2010, 6 жовтня). Про затвердження Типового положення про 
атестацію педагогічних працівників (930). https:// zakon.rada.gov.ua/laws/show/z1255-10

Міністерство освіти і науки України. (2016). Нова українська школа. Концептуальні засади реформування середньої школи. https://mon.gov.ua/storage/ app/media/zagalna\%20serednya/nova-ukrainskashkola-compressed.pdf

Міністерство освіти і науки України. (2018, 22 травня). Положення про психологічну службу у системі освіти України (509). https://zakon.rada.gov.ua/ laws/show/z0885-18

Міністерство освіти і науки України. (2019, 18 липня). Про пріоритетні напрями роботи психологічної служби у системі освіти на 2019-2020 н.р. (1/9462). https://bit.ly/3d4unia

Міністерство освіти і науки України. (2020, 19 травня). Міністерство освіти і науки України пропонує до громадського обговорення проєкт постанови КМУ «Про затвердження Положення про чентр професійного розвитку педагогічних працівників». https://bit.ly/3fs8OJY

Панок, В., Титаренко, Т., Чепелєва, Н., Рибалка, В., Маценко, В., Кісарчук, З., Дзюбко, Л., Юрченко, Т.,
Гврітішвілі, Н., Осадько, О., Уманець, Л., Онищенко, Г., Мацнєва, Н., Ставицька, О., Пов'якель, Н., Плахотникова, Н., Терлецька, Л., Пінчукова, Л., \& Усачова, Л. (2006). Основи практичної психології : підручник для студентів вищих навчальних закладів (3-є вид., стер.). Київ: Либідь, 2006.

Панок, В.Г. (2012). Психологічна служба: навчальнометодичний посібник для студентів і викладачів. Кам'янець-Подільський: ТОВ Друкарня Рута.

Панок, В.Г. (2017). Прикладна психологія. Теоретичні проблеми : монографія Київ: Ніка-Центр. https:// lib.iitta.gov.ua/707672/

Панок, В.Г. (2019). Процеси синтезу в психології (відкриття у науковій творчості Л.С. Виготського). Вісник ХНПУ імені Г.С. Сковороди «Психология», (60), 25-54. https://doi.org/10.34142/23129387.2019.60.02

Рибалка, В.В. (2017). Методологічні проблеми наукової психології : посібник. Київ: Талком. https:// lib.iitta.gov.ua/705937/

Яценко, Т.С. (2004). Теорія і практика групової психокорекції: Активне соціально-психологічне навчання : навчальний посібник. Київ: Вища школа.

\title{
THE CONCEPT OF PSYCHOLOGICAL SUPPORTING THE EDUCATION REFORMS IN THE PSYCHOLOGICAL SERVICE ACTIVITIES
}

\author{
Vitalii Panok \\ DSc in Psychology, Professor, Corresponding Member of NAES of Ukraine, Director, \\ Ukrainian Scientific and Methodological Center of Applied Psychology and Social Work, \\ National Academy of Educational Sciences of Ukraine, Kyiv, Ukraine
}

\begin{abstract}
The issues of improving the education system psychological service are considered in the paper. The main problems and challenges facing today with the education system reforming are identified based on the analysis of the psychological service practice in education institutions. The author proposes his vision of the ways to develop and improve the psychological service by understanding it as a unified system which provides psychological support for education process.

Keywords: education reform; psychological support; psychological service; practical psychologists; social educators; theory of a personality development; purpose of activity; principles; structure; licensing.
\end{abstract}

